\title{
Idiopathic Nephrotic Syndrome in Childhood: A Retrospective Analysis of Two Hundred and Eighty Nine Patients
}

\author{
Çocukluk Çağında Idiyopatik Nefrotik Sendrom: iki Yüz Seksen Dokuz Hastanın Retrospektif Analizi
}

\author{
Kenan Yılmaz, Ruhan Düşünsel* , İsmail Dursun* , Sibel Yel* , Zübeyde Gündüz* , \\ Hakan Poyrazoğlu*
}

Şanlıurfa Training and Research Hospital, Clinic of Pediatric Nephrology, Şanlıurfa, Turkey

*Erciyes University Medical Faculty Hospital, Clinic of Pediatric Nephrology, Kayseri, Turkey

Abstract

\begin{abstract}
Aim: In this study, we aimed to evaluate the demographic and histopathological characteristics and response to medications in children with idiopathic nephrotic syndrome in Turkey.
\end{abstract}

Methods: We reviewed medical records of patients older than one year, who were newly diagnosed with nephrotic syndrome and had been followed for at least one year in our department between November 1994 and March, 2013.

Results: A total of 289 children (169 boys) were included in the study. Fifty theree patients (18.4\%) were with steroid-resistant nephrotic syndrome, 33 (11.4\%) with frequently relapsing nephrotic syndrome and 53 (18.4\%) were with steroid-dependent nephrotic syndrome. Cyclosporine A (CsA), cyclophosphamide, mycophenolate mofetil, levamisole, azathioprine, and rituximab were used as steroid-sparing agents in some patients. The number of patients who were responder to steroid and to CSA was similar. Majority of patients with steroidresistant nephrotic syndrome were also resistant to mycophenolate mofetil and CsA.

Conclusion: There was a high prevalence of minimal change disease based on kidney biopsy especially in boys younger than six years of age and response to steroid and CSA was almost similar.

Keywords: Children, idiopathic nephrotic syndrome, steroid resistance, steroid dependent, relapse
Amaç: Bu çalışma, Türkiye'de idiyopatik nefrotik sendrom tanısı alan çocukların demografik verileri ve histopatolojik özelliklerinin yanı sıra özellikle steroid ve steroid dışı tedaviye yanıtlarıyla ilgili yeterli çalışma olmaması nedeniyle yapıldı.

Yöntemler: Departmanımızda Kasım 1994 - Mart 2013 tarihleri arasında ilk kez idiyopatik nefrotik sendrom tanısı alan, bir yaş üzerinde ve en az bir yıl süreyle takip edilen hastaların tıbbi kayıtları incelendi.

Bulgular: Bu çalışmaya toplam 289 çocuk (169 erkek) dahil edildi. Hastaların 53'ü $(\% 18,4)$ steroid dirençli nefrotik sendrom, 33'ü $(\% 11,4)$ sık tekrarlayan nefrotik sendrom, 53'ü $(\% 18,4)$ steroid bağımlı nefrotik sendrom idi. Hastalarda kullanılan alternatif ajanlar siklosporin A (CSA), siklofosfamid, mikofenolat mofetil, yüksek doz metilprednizolon, levamizol, azatioprin ve ritüksimab idi. Steroid ile CSA'ya yanıt arasında benzerlik olduğu görüldü $(p<0,01)$. Steroid direnci olan hastaların büyük bir kısmı Mikofenolat mofetil ve CSA tedavisine de direnç gösteriyordu.

Sonuç: Özellikle altı yaş altındaki erkek çocukların böbrek biyopsilerinde minimal lezyon hastalığının yüksek sıklıkta görüldüğü ve steroid tedavisi ile CSA tedavisine yanıtın benzer olduğu bulunmuştur.

Anahtar Sözcükler: Çocuklar, idiyopatik nefrotik sendrom, steroid direnci, steroid bağımlı, relaps

\section{Introduction}

Nephrotic syndrome (NS) is characterized by massive proteinuria, generalized edema, hypoalbuminemia and hyperlipidemia. Idiopathic NS (INS) is the most common form of NS (>90\%) with annual incidence of 1 to 3:100.000 in children below 16 years of age (1).
Although majority of children with INS are well responder for steroids, $20 \%$ of them are steroid-resistant. Therapeutic response to medications and long-term outcome of the disease may be different between the geographic regions (2). However, there are few studies on this topic. Thus, in this study, our aim was to evaluate the
Address for Correspondence/Yazışma Adresi: Kenan Yılmaz Şanlıurfa Training and Research Hospital, Clinic of Pediatric Nephrology, Şanlıurfa, Turkey E-mail: kenanylmz68@hotmail.com ORCID ID: orcid.org/0000-0001-5679-5429

Received/Geliş Tarihi: 15 April 2017 Accepted/Kabul Tarihi: 9 November 2017
${ }^{\circ}$ Copyright 2017 by The Medical Bulletin of University of Health Sciences Haseki Training and Research Hospital
The Medical Bulletin of Haseki published by Haseki published by Galenos Yayınevi.

Telif Hakkı 2017 Sağlık Bilimleri Üniversitesi Haseki Eğitim ve Araştırma Hastanesi Haseki Tıp Bülteni, Galenos Yayınevi tarafından basıımıştır. 
demographic and histopathological characteristics, and response to medications in children with INS in our center

\section{Methods}

We reviewed medical records of children diagnosed with INS in the pediatric nephrology department at Erciyes University, between November 1994 and March 2013. Our study was conducted in accordance with the principles of the Helsinki Declaration. Ethics Committee of Erciyes University Medical Faculty approved the study (approval no: 2014/582). Inclusion criteria were; 1) At least one year of follow-up after diagnosis, and 2) $\geq 1$ year of age at the time of diagnosis. Children with secondary NS were excluded. Patient's charts were retrospectively reviewed in terms of demographic, histopathologic and clinical findings, and response to immunosuppressive treatment.

NS was defined as edema, proteinuria $\left(\geq 40 \mathrm{mg} / \mathrm{m}^{2} /\right.$ hour) and hypoalbuminemia (serum albumin level $<2.5 \mathrm{~g} /$ $\mathrm{dL}$ ). The classifications of the patients based on steroid response were as follows (2):

1. Complete remission: Urine protein creatinine ratio (UPCR) $<200 \mathrm{mg} / \mathrm{g}$ or $<1+$ protein on a urine dipstick measurement for three consecutive days.

2. Partial remission: Fifty percent or more decrease in proteinuria and UPCR between 200 and $2000 \mathrm{mg} / \mathrm{g}$.

3. No remission: Failure to reduce urine protein excretion by $50 \%$ from baseline or persistent excretion uPCR $>2000 \mathrm{mg} / \mathrm{g}$.

4. Steroid-resistant NS (SRNS): Failure to achieve complete remission after eight weeks of corticosteroid therapy.

5. Relapse: uPCR $\geq 2000 \mathrm{mg} / \mathrm{g}$, or $\geq 300 \mathrm{mg} / \mathrm{dL}$ or $3+$ protein on urine dipstick.

6. Frequently relapsing NS (FRNS): Two or more relapses within six months of initial response, or four or more relapses in any 12-month period.

7. Steroid-dependent NS (SDNS): Two consecutive relapses during corticosteroid therapy, or within 14 days of ceasing therapy.

8. Early nonresponder: Failure to achieve complete remission after eight weeks of corticosteroid therapy.

9. Late nonresponder: Persistent proteinuria during four or more weeks of corticosteroids following one or more remission.

Renal biopsy was routinely performed in patients with gross hematuria, persistent microscopic hematuria, increased serum creatinine, resistance to steroid, low serum complement and age at onset $<1$ y or $>8$ y. The biopsy specimens were examined by light and immunofluorescence microscopy. Steroid therapy was initiated at a dose of $60 \mathrm{mg} / \mathrm{m}^{2} /$ day over four weeks, which then titrated to $60 \mathrm{mg} / \mathrm{m}^{2}$ on alternate days over an additional four weeks. The dose was then tapered over the next two-three months and discontinued. Alternative agents used in patients with SDNS, SRNS and FRNS were: cyclosporine A (CsA) 3-5 mg/kg/day, oral cyclophosphamide (CYC) $2 \mathrm{mg} / \mathrm{kg} /$ day (maximum cumulative dose: $168 \mathrm{mg} / \mathrm{kg}, 8-12$ weeks), intravenous CYC500 mg/m²/month (3-6 months), mycophenolate mofetil (MMF) $600 \mathrm{mg} / \mathrm{m}^{2} /$ dose (twice daily), pulse methylprednisolone $30 \mathrm{mg} / \mathrm{kg}$ (maximum: $1000 \mathrm{mg}$ ), levamisole $2-3 \mathrm{mg} / \mathrm{kg} /$ day, azathioprine $1-3 \mathrm{mg} / \mathrm{kg} /$ day, and rituximab $375 \mathrm{mg} / \mathrm{m}^{2}$.

CsA and MMF resistance were defined as failure to achieve partial or complete remission after six months of CSA and MMF treatment (2).

\section{Statistical Analysis}

Data were analyzed by using IBM SPSS version 21 software. The Shapiro-Wilk test was used to assess normality in numeric variables. The Mann-Whitney $U$ test was used for comparison between groups with skewed distribution while the Kruskal-Wallis test was used for comparison among groups. Chi-square test was used for comparisons between categorical variables. A p value of less than 0.05 was considered statistically significant.

\section{Results}

A total of 289 children were included in the study. Of these, 169 (58.5\%) were boys and 120 (41.5\%) were girls. The mean age at the time of diagnosis was 40 months (range: 12-180 months). The mean follow-up time was 76 months (range: 12-204 months). On the first admission, there was oliguria in 134 (46.4\%), hypertension in 54 $(18.7 \%)$, massive edema in $47(16.3 \%)$, microscopic hematuria in $39(13.5 \%)$ and gross hematuria in two (0.7\%) patients.

The number and mean age of the patients without relapse were $58(20.1 \%)$ and 48 months (minimummaximum: 165 months), respectively. $46.6 \%$ of them were girls. The boys less than 6 of age were more steroid resistant (51\% in SRNS group). Only 29 patients (10\%) had a glomerular filtration rate of $<90 \mathrm{~mL} / \mathrm{min} / 1.73 \mathrm{~m}^{2}$ at presentation. Of the patients $53(18.4 \%)$ were with SRNS, $33(11.4 \%)$ with FRNS and 53 (18.4\%) were with SDNS. Kidney biopsy was performed in 72 patients; initial renal histology showed minimal change disease (MCD) in 43 patients (59.7\%), focal segmental glomerulosclerosis(FSGS) in $12(16.7 \%)$, mesangioproliferative glomerulonephritis in $8(11.1 \%)$, membranoproliferative glomerulonephritis in 6 $(8.3 \%)$ and membranous glomerulonephritis in 3 patients (4.2\%). Ninety five patients $(32.9 \%)$ required albumin replacement for effective intravascular volume. 37.2\% of patients with MCD at the initial biopsy were steroidresistant (Table 1). Similarly, majority of them were also resistant to MMF and CSA. The response rate to CYC in 
this group was approximately 50\% (Table 2). The response rate to MMF and CYC in SRNS group was 36\% and 54\%, respectively. Majority of the children who were responder to steroid were also responder to CsA $(86.6 \%)(p<0.01)$.

Rituximab therapy was given in two patients. Of them, one was steroid-dependent and the other one was steroidresistant.

Eleven patients were treated with levamisole. Of them, only one responded to the therapy (Table 3).

The most common complications related to disease and medication were osteoporosis and hypertrichosis (Table 4). Of the patients with osteoporosis, 29 patients $(54.7 \%)$ were in SRNS group, 16 patients $(30.2 \%)$ in SDNS group and eight patients (15.1\%) in FRSN group. Hypertension was detected in eight $(61.5 \%)$ patients with SRNS. Five of them had MCD based on kidney biopsy. All the patients were alive in the course of the study.
The distribution of the patients with hypertension according to steroid response was as follows: eight patients (61.5\%) with SRNS, two patient (15.4\%) with SDNS and three patients (23.1\%) with FRNS. Based on the biopsy results, there was MCD in five patients (38.5\%), FSGS in four patients (30.8\%) and mesangial proliferative glomerulonephritis in two patients (15.4\%).

Four patients progressed to end-stage renal disease (ESRD) at the end of the follow-up.

\section{Discussion}

The present study demonstrates that boys younger than six years of age show a higher incidence of steroid resistance and that the rate of response to steroid and CSA is similar. In addition, hypertension and osteoporosis are common complications in patients with SRNS as expected.

INS is more common in boys than in girls with a ratio

\begin{tabular}{|c|c|c|c|c|c|c|}
\hline Biopsy result & $\mathbf{n}$ & MCD & MesPGN & FSGS & MPGN & MGN \\
\hline \multicolumn{7}{|l|}{ Age at diagnosis } \\
\hline$\leq 6$ years & 47 & $31(72.1 \%)$ & $3(37.5 \%)$ & $10(83.3 \%)$ & $1(16.7 \%)$ & $2(66.7 \%)$ \\
\hline$>6$ years & 25 & $12(27.9 \%)$ & $5(62.5 \%)$ & $2(16.7 \%)$ & $5(83.3 \%)$ & $1(33.3 \%)$ \\
\hline \multicolumn{7}{|l|}{ Gender } \\
\hline Girls & 36 & $21(48.8 \%)$ & $4(50 \%)$ & $4(33.3 \%)$ & $4(66.7 \%)$ & $3(100 \%)$ \\
\hline Boys & 36 & $22(51.2 \%)$ & $4(50 \%)$ & $8(66.7 \%)$ & $2(33.3 \%)$ & 0 \\
\hline \multicolumn{7}{|l|}{ Steroid response } \\
\hline Frequent relapse & 17 & $12(27.9 \%)$ & $3(37.5 \%)$ & $1(8.3 \%)$ & 0 & $1(33.3 \%)$ \\
\hline Steroid-dependent & 16 & $11(25.6 \%)$ & $1(12.5 \%)$ & $2(16.6 \%)$ & $2(33.3 \%)$ & 0 \\
\hline Steroid-resistant & 33 & $16(37.2 \%)$ & $3(37.5 \%)$ & $9(75 \%)$ & $4(66.7 \%)$ & $1(33.3 \%)$ \\
\hline Steroid-sensitive & 6 & $4(9.3 \%)$ & $1(12.5 \%)$ & - & - & $1(33.3 \%)$ \\
\hline
\end{tabular}

\begin{tabular}{|l|l|l|l|l|l|l|}
\hline Table 2. The relationship between steroid response and non-steroid therapy \\
\hline \multirow{2}{*}{ Steroid response } & CsA & MMF & CYC \\
\cline { 2 - 7 } & Response & No response & Response & No response & Response & No response \\
\hline SRNS & 4 & 11 & 4 & 7 & 6 & 5 \\
\hline FRNS & 14 & 1 & 2 & 0 & 15 & 2 \\
\hline SDNS & 12 & 3 & 1 & 0 & 8 & 4 \\
\hline $\begin{array}{l}\text { CSA: Cyclosporine A, a: Majority of the children responsive to steroid were also responsive to CSA (p<0.01), SRNS: Steroid-resistant nephrotic syndrome, FRNS: Frequently } \\
\text { relapsing nephrotic syndrome, SDNS: Steroid-dependent nephrotic syndrome, MMF: mycophenolate mofetil, CYC: Cyclophosphamide }\end{array}$ \\
\hline
\end{tabular}

Table 3. Rate, duration and response rate of non-steroid therapy
\begin{tabular}{|l|l|l|l|l|l|l|}
\hline Non-steroid therapy & CsA & MMF & CYC & RTX & AZA & Lev \\
\hline Number $\mathrm{n}(\%)$ & $45(15.6)$ & $14(4.8)$ & $40(13.8)$ & $2(0.7)$ & $11(3.8)$ & $11(3.8)$ \\
\hline Responder $\mathrm{n}(\%)$ & $30(66.6)$ & $7(50)$ & $29(72.5)$ & $1(50)$ & $3(27.2)$ & $1(9)$ \\
\hline Non-responder $\mathrm{n}(\%)$ & $15(33.3)$ & $7(50)$ & $11(27.5)$ & $1(50)$ & $8(72.8)$ & $10(91)$ \\
\hline Duration (months)* & $26(6-64)$ & $26(10-44)$ & - & - & $14(9-36)$ & $12(4-24)$ \\
\hline *: Median (minimum-maximum) CsA: Cyclosporine A, MMF: Mycophenolate mofetil, CYC: Cyclophosphamide, RTX: Rituximab, AZA: Azathiopyrin, Lev: Levamisole \\
\hline
\end{tabular}


of 4:1 for new cases of NS. The peak age for the onset of NS is 2-3 years $(3,4)$. In the previous studies in our country, male predominance was shown and average age of onset was 3-6 years (5-7). In our cohort, 58.5\% of patients were boys and they experienced more steroid resistance.

One of the cardinal findings of INS in children is good response to steroid (8). Initially, response rate to steroid has been reported to be between $77.6 \%$ and $88 \%$ in different studies and the outcome was found to be better in patients who responded to steroid when compared to those who were resistant to steroid $(9,10)$. The rate of steroid resistance has been reported to be approximately $20 \%$ in the literature (1). In the current study, the rate of response to steroid was found to be $81.7 \%$. Resistance to steroid was detected in $18.3 \%$ of children with INS which was similar with that in a previous study performed in our country (5).

In 1978, the International Study of Kidney Disease in Children reported that $77 \%$ and $7 \%$ of childhood INS consisted of MCD and FSGS, respectively (11). In our study, MCD was the most common histopathological finding in children under the age of six. It was followed by FSGS. Recently, many studies have revealed that the frequency of the diagnosis of FSGS has been increased year by year (1215). In our study, FSGS was detected in $16.6 \%$ of patients who underwent kidney biopsy and $75 \%$ of them had steroid resistance. Our findings were compatible with that of the study by Boyer et al. (16) which showed increased steroid resistance over the past two decades. FSGS is a histopathological finding of poor prognosis leading to the development of ESRD in patients with NS (17). In our study, we showed that $1.4 \%$ of our patients progressed to ESRD and all of them were diagnosed with FSGS.

In this study, an interesting finding was the presence of steroid resistance in $37.2 \%$ of patients who had MCD based on kidney biopsy findings. $81 \%$ of them were boys and the mean age at the diagnosis was 27 months (12-43 months). Thus, we think that younger boys were at risk for steroid resistance even in biopsy-proven MCD.

\begin{tabular}{|l|l|l|l|l|}
\hline \multicolumn{6}{|l|}{ Table 4. Complications related to disease itself and drugs } \\
\hline Complications & SRNS & FRNS & SDNS & $\mathbf{n}(\%)$ \\
\hline Osteoporosis & 29 & 16 & 8 & $53(18.3)$ \\
\hline Hypertrichosis & 22 & 9 & 6 & $37(12.8)$ \\
\hline Alopecia & 8 & 7 & 4 & $19(6.6)$ \\
\hline Hypertension & 8 & 3 & 2 & $13(4.5)$ \\
\hline Peritonitis & 5 & 3 & 1 & $9(3.1)$ \\
\hline Cataract & 2 & 2 & 3 & $7(2.4)$ \\
\hline Hypothyroidism & 3 & 1 & 0 & $4(1.4)$ \\
\hline Thromboembolism & 2 & 0 & 0 & $2(0.7)$ \\
\hline $\begin{array}{l}\text { SRNS: Steroid-resistant nephrotic syndrome, FRNS: Frequently relapsing } \\
\text { nephrotic syndrome, SDNS: Steroid-dependent nephrotic syndrome }\end{array}$ \\
\hline
\end{tabular}

The remission rate for CsA has been reported to be between $60 \%$ and $90 \%$ (18-20). In our study, this rate was found to be $66.6 \%$ and the patients showed similar response to steroid and CSA. In a recent study performed in our country, full and partial remissions were observed with a rate of $85 \%$ with the use of Cs (5). Recently, MMF has been a commonly used steroid-sparing agent in childhood NS. In patients with SRNS, MMF gave rise to complete remission in $23-62 \%$ of patients and partial remission in $25-37 \%$ of patients (21-23). In our study, we used MMF with a mean duration of 26 months (10-44 months) and complete remission was achieved in $50 \%$ of patients. It failed in the remaining 50\%.

CYC has been used to reduce relapse frequency and to induce long-term remission. In a meta-analysis including 102 children from three trials performed in children with relapsing steroid-sensitive NS, CYC significantly reduced the relapse risk at 6-12 months compared to prednisone alone (24). The response rate to CYC was $72.5 \%$ in our cohort. In addition, majority of patients who achieved remission with CYC were sensitive to steroid (79.3\%). Only half of the patients with SRNS were responder to CYC.

Isolated case reports have shown a beneficial effect of rituximab in pediatric patients with primary FSGS (25). We used rituximab in two patients with SRNS who received steroids, CsA, CYC and MMF previously. Both patients were diagnosed with FSGS. One of them did not benefit from rituximab and progressed to ESRD; renal transplantation was performed ultimately in this patient. The second achieved complete remission and was clinically doing well at the last follow-up visit.

Levamisole is an antihelminthic agent and also used as a steroid-sparing agent in children with SDNS and/or FRNS. Al-Saran et al. (26) studied the effect of levamisole on FRNS/SDNS. They showed that 20 patients (62.5\%) were relapse-free during the follow-up in levamisole group while no patient was relapse-free in control group. In our study, levamisole was given to 11 patients including five patients in SRNS group and six patients in SSNS group. None of the patients in SRNS group responded to levamisole. Only one child (16.6 \%) in SSNS group was responder to levamizole.

It is well-known that complications may be observed due to disease itself or medications used in NS $(27,28)$. In our study, the most common complication was osteoporosis, followed by hypertrichosis, alopecia, hypertension, peritonitis, cataract, hypothyroidism, and thromboembolism (Table 4).

Our study has several limitations associated with the retrospective design of the study. For example, the number of patients who underwent kidney biopsy and the number of patients who were given MMF and rituximab 
are limited. In addition, it was a single center study and etiology of INS was not uniform.

\section{Conclusion}

In conclusion, there is a high prevalence of MCD based on kidney biopsy especially in boys younger than six years of age and response to steroid and CSA is almost similar. We assume that prospective clinical studies with large number of patients should be done to evaluate the effect of the new steroid-sparing agents on outcome in children with INS.

\section{Ethics}

Ethics Committee Approval: Ethics Committee of Erciyes University Medical Faculty approved the study. (approval no: 2014/582).

Informed Consent: It was taken.

Peer-review: Externally and internally peer-reviewed.

\section{Authorship Contributions}

Surgical and Medical Practices: K.Y., I.D. Concept: R.D., Z.G. Design: H.P., R.D. Data Collection or Processing: K.Y., S.Y. Analysis or Interpretation: I.D., Z.G. Literature Search: K.Y., I.D. Writing: K.Y.

Conflict of Interest: No conflict of interest was declared by the authors.

Financial Disclosure: The authors declared that this study received no financial support.

\section{References}

1. McKinney PA, Feltbower RG, Brocklebank JT, Fitzpatrick MM. Time trends and ethnic patterns of childhood nephrotic syndrome in Yorkshire, UK. Pediatr Nephrol 2001;16:1040-4.

2. Lombel RM, Gipson DS, Hodson EM; Kidney Disease: Improving Global Outcomes. Treatment of steroid-sensitive nephrotic syndrome: new guidelines from KDIGO. Pediatr Nephrol 2013;28:415-26.

3. Niaudet $P$, Boyer $O$. Idiopathic nephrotic syndrome in childhood: clinical aspects. In: Avner ED, Harmon WE, Niaudet P, Yoshikawa N, editors. Pediatric Nephrology. 6th ed. Berlin Heidelberg: Springer-Verlag; 2009. p. 667-92.

4. Spencer JD, Hastings MC, Wyatt RJ, Ault BH. Has the incidence of childhood steroid sensitive nephrotic syndrome changed? Clin Nephrol 2012;78:112-5.

5. Hacıhamdioğlu DÖ, Kalman S, Faysal Gök F. Long-term results of children diagnosed with idiopathic nephrotic syndrome; single center experience. Turk Pediatri Ars 2015;50:37-44.

6. Van A, İşlek I, Dağdemir A, Koçak H, Küçükködük Ş. Çocukluk çağı nefrotik sendromu: 230 olgunun değerlendirilmesi. OMÜ Tip Dergisi 2001;18:71-9.

7. Peru H, Karagöl C, Elmacı AM, Kara F. Nefrotik Sendromlu141 olgunun retrospektif analizi. Selçuk Tıp Derg 2008;25:23-9.
8. Bagga A, Mantan M. Nephrotic syndrome in children. Indian J Med Res 2005;122:13-28.

9. Safaei A, Maleknejad S. Spectrum of childhood nephrotic syndrome in Iran: a single center study. Indian J Nephrol 2009; 19:87-90.

10. Gulati S, Kher V, Sharma RK, Gupta A. Steroid response pattern in Indian children with nephrotic syndrome. Acta Pediatr 1994;83:530-3.

11. No authors listed. Nephrotic syndrome in children: prediction of histopathology from clinical and laboratory characteristics at time of diagnosis. A report of the International Study of Kidney Disease in Children. Kidney Int 1978;13:159-65.

12. Chesney R. The changing face of childhood nephrotic syndrome. Kidney Int 2004;66:1294-302.

13. Hogg R, Middleton J, Vehaskari VM. Focal segmental glomerulosclerosis- epidemiology aspects in children and adults. Pediatr Nephrol 2007;22:183-6.

14. Batinic $D$, Miloševic $D$, Coric $M$ et al. Idiopathic nephrotic syndrome in children: review of 282 Croatian cases. Clin Nephrol 2012;78:116-21.

15. Korbet SM. Treatment of primary focal segmental glomerulosclerosis. Kidney Int 2012;62:2301-10.

16. Boyer O, Moulder JK, Somers MJ. Focal and segmental glomerulosclerosis in children: a longitudinal assessment. Pediatr Nephrol 2007;22:1159-66.

17. Sozeri B, Mir S, Mutlubas F, Sen S. The long-term results of pediatric patients with primary focal and segmental glomerulosclerosis. Saudi J Kidney Dis Transpl 2010;21:87-92.

18. El-Husseini A, El-Basuony F, Mahmoud I, et al. Long-term effects of cyclosporine in children with idiopathic nephrotic syndrome: a single-centre experience. Nephrol Dial Transplant 2005;20:2433-8.

19. Hulton SA, Neuhaus TJ, Dillon MJ, Barratt TM. Long-term cyclosporin A treatment of minimal-change nephrotic syndrome of childhood. Pediatr Nephrol 1994;8:401-3.

20. Niaudet P, Broyer M, Habib R. Treatment of idiopathic nephrotic syndrome with cyclosporin $A$ in children. Clin Nephrol 1991;35:31-6.

21. Lombel RM, Hodson EM, Gipson DS; Kidney Disease: Improving Global Outcomes. Treatment of steroid-resistant nephrotic syndrome in children: new guidelines from KDIGO. Pediatr Nephrol 2013;28:409-14.

22. Li Z, Duan C, He J, et al. Mycophenolate mofetil therapy for children with steroid-resistant nephrotic syndrome. Pediatr Nephrol 2010;25:883-8.

23. de Mello VR, Rodrigues MT, Mastrocinque TH, et al. Mycophenolate mofetil in children with steroid/ cyclophosphamide-resistant nephrotic syndrome. Pediatr Nephrol 2010;25:453-60.

24. Hodson EM, Willis NS, Craig JC. Non-corticosteroid treatment for nephrotic syndrome in children. Cochrane Database Syst Rev 2008:CD002290. 
25. Kemper MJ, Lehnhardt A, Zawischa A, Oh J. Is rituximab effective in childhood nephrotic syndrome? Yes and no. Pediatr Nephrol 2014;29:1305-11.

26. Al-Saran K, Mirza K, Al-Ghanam G, Abdelkarim M. Experience with levamisole in frequently relapsing, steroid dependent nephrotic syndrome. Pediatr Nephrol 2006;21:201-5.
27. Park SJ, Shin Jl. Complications of nephrotic syndrome. Korean J Pediatr 2011;54:322-8.

28. Cadnapaphornchai MA, Tkachenko O, Shchekochikhin D, Schrier RW. The nephrotic syndrome: pathogenesis and treatment of edema formation and secondary complications. Pediatr Nephrol 2014;29:1159-67. 